\title{
Retóricas do capital: entre o discurso e a práxis, a produção de desigualdades
}

\author{
Danilo Barbosa de Arruda ${ }^{1}$ (D) \& Geraldo Milioli ${ }^{1,2}$ (C)
}

(1) Universidade do Extremo Sul Catarinense, Programa de Pós-Graduação em Ciências Ambientais, Avenida Universitária 1105, Universitário 88806-000, Criciúma, Santa Catarina, Brasil. E-mail: danilobarruda@gmail.com

(2) Universidade do Extremo Sul Catarinense, Avenida Universitária 1105, Universitário 88806-000, Criciuma, Santa Catarina, Brasil. E-mail: gmi@unesc.net

Arruda D.B. \& Milioli G. (2020) Retóricas do capital: entre o discurso e a práxis, a produção de desigualdades. Pesquisa e Ensino em Ciências Exatas e da Natureza, 4: e1342.

http://dx.doi.org/10.29215/pecen.v4i0.1342

Editora acadêmica: Raimunda de Fátima Neves Coêlho. Recebido: 31 Janeiro 2020. Aceito: 13 Abril 2020. Publicado: 16 Abril 2020.

Resumo: O objeto do artigo em tela é questionar os discursos e retóricas do capital na interface do sistema econômico, que provoca conflitos e desigualdade econômico-social. A problemática apresentada postula que as desigualdades sociais são oriundas de decisões político-econômicas e circunstâncias históricas, espaciais e temporais e estão aumentando na atualidade. $\mathrm{O}$ principal referencial teórico utilizado foi extraído de relatórios da OXFAM, Banco Mundial, Relatório de Desenvolvimento Humano, Pacto Internacional dos Direitos Econômicos, Sociais e Culturais (PIDESC), e os autores Altvater e Acselrad. Por meio da análise qualitativa de material bibliográfico e dados secundários dos mencionados organismos nacionais e internacionais é feito uma releitura dos mecanismos de poder, relacionando o controle e usos do território e seus recursos para produção e concentração de riquezas. Como resultado, tem-se que a reprodução das desigualdades que permeiam as relações sociais são retroalimentadas por um macrocenário hostil à consolidação dos direitos sociais, excluindo e marginalizando periferias.

Palavras chave: Neoliberalismo, crise, desenvolvimento, desigualdade, periferia, neocolonialismo.

\section{The rhetoric of capital: between discourse and praxis, the production of inequality}

Abstract: The aimed of this article is to question the discourses and rhetoric of capital at the interface of the economic system, which causes conflicts and economic-social inequality. The presented problem postulates that social inequalities are derived from political-economic decisions and historical, spatial and temporal circumstances which have increased nowadays. The main theoretical references used were the reports from OXFAM, World Bank, Human Development Report, International Covenant on Economic, Social and Cultural Rights (ICESCR) and the authors Altvater and Acselrad. Through the qualitative analysis of bibliographic material and secondary data from the aforementioned national and international organizations, a review of the mechanisms of power is made, relating the control and uses of the territory and its resources for the production and concentration of riches. As a result, there is a reproduction of the inequalities that permeate the social relations fed back by a hostile macrocenary to the consolidation of social rights, excluding and marginalizing peripheries.

Key words: Neoliberalism, crisis, development, inequality, periphery, neocolonialism.

\section{Introdução}

Diante do espectro pós crise financeira de 2008, revoluções e quedas de ditadores, migrações forçadas, seja por motivos militares, ambientais, catástrofes ou acentuamento da crise econômico-social, urge a necessidade de se repensar, questionar e apontar as possíveis motivações da origem das relações urbanas assimétricas. 
Nesse sentido, de modo sintético, o presente artigo traça uma trajetória históricocomparativa entre a colonização e suas periferias, a metrópole central enquanto concentradora de decisões e detentora do poder político-econômico e a realidade atroz das periferias do Hemisfério Sul ou Sul Global. No sentido de que, historicamente a periferia do capital, a periferia global, compreendida como os países pobres ou subdesenvolvidos, foram e ainda o são utilizadas como sumidouro dos rejeitos do progresso e desenvolvimento econômico.

$\mathrm{Na}$ primeira seção, busca-se contextualizar o desenvolvimento das retóricas desenvolvimentistas, das margens socioeconômicas e ambientais e da imposição neo(colonial) dos instrumentos de poder, controle, exploração e domínio do capital, logo, também da cidade, seus acessos e usufruto, por parte de uma ínfima parcela da população, mediante o processo da analogia do uso dos recursos naturais e humanos, do todo ou central para as margens, bordas ou periferia. Assim, a urbanização, as relações humanas na sociedade contemporânea se fragmentaram e houve um racionalismo por parte dos estudiosos e cientistas sociais. Some-se a isto o fato de políticos serem seduzidos pelo mercado fazendo uso dos poderes instituídos para legalizar e universalizar equivocadas decisões de cunho segregador.

Nessa conjuntura, a segunda seção do manuscrito trabalha as consequências do capital, implicações da exclusão urbana e gentrificação, pressão demográfica e a crise na e da cidade emergente. A lógica do condomínio encontra espaço para se instalar e reproduzir-se, tomar corpo junto às desigualdades já existentes e piorar a qualidade de vida nas cidades. Nessa nuance, a cidade vem se erguendo como um campo de batalhas, um conflito antes um pouco mais latente e agora manifesto entre as classes sociais que ocupam o espaço urbano.

Em detrimento da real democracia e cumprimento dos dispositivos jurídicos para efetivação dos direitos sociais persiste a (re)produção das desigualdades dentro dos países periféricos e entre estes e os desenvolvidos, há uma dinâmica singular que converge para a manutenção do modelo econômico vigente devido à infinita crença no mercado, nas resoluções tecnológicas dos problemas socioambientais e também por causa da inerente divisão internacional do trabalho.

\title{
1. Facetas do desenvolvimento no sul global: direitos sociais versus discurso desenvolvimentista
}

Entre o discurso e a prática de políticas ambientais adotadas pelos estados nacionais que compõem a América Latina, o esvaziamento das questões ambientais se dá no plano efetivo nos campos econômico, social, político, histórico e cultural. Na contramão dos pressupostos de uma sociedade que assume cada vez mais um compromisso formal com a sustentabilidade, os países latinoamericanos produzem e perpetuam em seus territórios um modelo hegemônico único que agride direitos sociais, humanos e ambientais:

\begin{abstract}
é a cultura dominante que opera e legitima as distinções, definindo posições sociais, subculturas e sistemas simbólicos, obrigando dominados a se definirem sempre em referência à distância que mantêm em relação à cultura dominante. Os sistemas simbólicos, por sua vez, instrumentos de imposição ou de legitimação, reforçam as relações de força (políticas e econômicas) que fundamentam a dominação de uma classe sobre a outra. Há uma luta simbólica entre as diferentes classes e frações de classes, cada qual procurando impor sua própria definição de mundo, assim contribuindo para a reprodução social e para reforçar (ou enfraquecer) a crença na legitimidade da dominação de classe. $\mathrm{O}$ poder simbólico, portanto, é definido por uma relação determinada entre os que exercem o poder e os que a ele se submetem, sua força residindo na crença produzida e reproduzida no próprio campo em que se estruturam essas relações. (Viégas 2009: 149-150).
\end{abstract}

Quando o sujeito internacional é uma nação desenvolvida o interesse em considerar os impactos socioambientais têm magnitude distinta, pois os países ricos não querem administrar uma crise ecológica de consequências incalculáveis e estimam uma valoração diferente para seus cidadãos, sua cultura e modus vivendi. Logo, há uma tensão em que os estados mais poderosos lidam com a biodiversidade ${ }^{1}$ e recursos naturais dos países em desenvolvimento como produtos, mercadorias e serviços disponíveis em suas bolsas de valores. 
A ideia de que a Terra está se adequando nessa conjectura de mudanças antrópicas, induz que a população humana, dentre outras espécies, será reduzida ou levada a extinção para suportar a capacidade de carga. Essa proposição surge diante da crise sistêmica, dos fenômenos climáticos adversos, problemas ambientais e desordens sociais que, natural ou reforçados pelas ações humanas, tem expurgado o excesso de seres vivos e seu ritmo de vida, conduzindo a choque e tensões na modernidade, criando novas barreiras e inviabilizando um projeto de superação das adversidades.

Essa faceta cruel do marco civilizatório ao longo de séculos de exploração e usurpação das riquezas naturais existentes vem sobrepondo os interesses puramente economicistas de banqueiros, agentes públicos, executivos e elites nacionais que estão alinhadas com a globalização e neoliberalismo ${ }^{2}$. A ocultação disso se revela quando tragédias socioambientais atingem uma coletividade, trazendo perdas imensuráveis, tais como o genocídio de povos primitivos em diversos países da América do Sul e Central, problemas de poluição de solo e recursos hídricos, como desastre da barragem da mineradora Vale, em Mariana, MG, Brasil, explosão da plataforma da British Petroleum, no Golfo do México, entre o México, Ilhas do Caribe e Estados Unidos, vazamentos de petróleo e gás, dentre outros. Essa vertente tem impactos negativos que provocam externalidades socioambientais, dizimam espécies raras e deixa um prejuízo imenso além do passivo ambiental:
${ }^{1}$ Biodiversidade não é a diversidade de grandes animais (como elefantes ou focas). A biodiversidade aqui considerada é diversidade do estoque vivo, ou seja, diversidade de espécies microscópicas e diversidade dos estoques genéticos no seio das espécies, ambas constituindo o "germoplasma", a matéria-prima da indústria farmacêutica e de sementes e da biotecnologia. Por extensão, o debate sobre a biodiversidade trata da diversidade nos ecossistemas nos quais a "biodiversidade" pode existir (Lipietz 1997: 153).

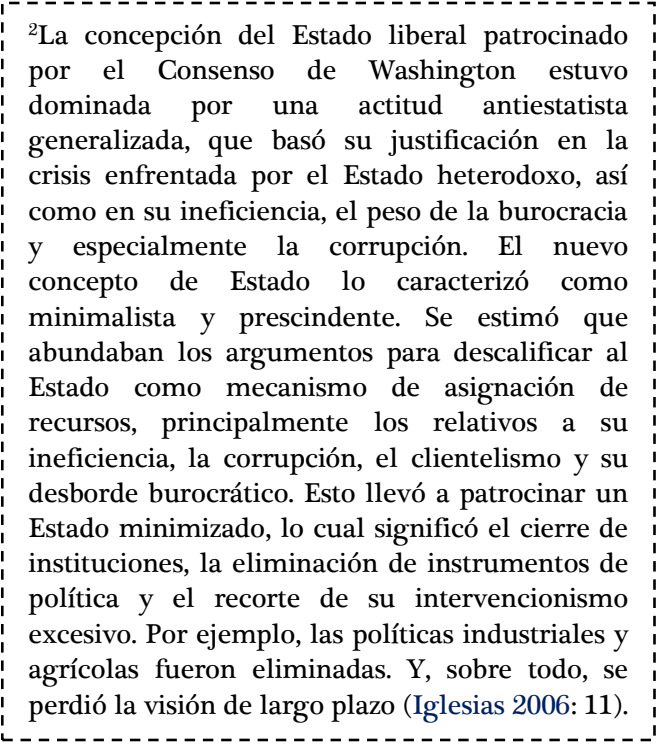

La apropiación de la naturaleza permite ejercer un control de ella legitimado y resguardado por la violencia del Estado. Ello normaliza patrones de exclusión por medio de los cuales se reproducen asimetrías de poder, inequidad y autoriza la sobreexplotación de recursos (Bustos et al. 2015: 28).

A apropriação da natureza e o controle exercido pela iniciativa privada e sociedade são legitimados e até respaldados pelo Estado. O Estado concebe a natureza e seus recursos, define seus usos e limites de exploração com fins estritamente comerciais, sob a ótica das relações puramente econômicas. Esse controle pode ser rateado com o mercado internacional, atribuindo preço para as matérias-primas ou simplesmente como segurança energética ou financeira nas bolsas em troca de empréstimos e pagamentos de juros da dívida pública. $\mathrm{O}$ neocolonialismo mostra a eficácia da divisão internacional do trabalho e as implicações sociopolíticas envolvidas nos empréstimos internacionais cedidos por organismos como Fundo Monetário Internacional (FMI), Banco Mundial e Banco Interamericano de Desenvolvimento:

Esse termo-neocolonialismo foi empregado por Nkrumah, primeiro-ministro de Gana (antiga Gold Coast), para definir "a situação de um Estado independente em teoria e dotado de todos os atributos da soberania, mas que, na realidade, tem sua política dirigida a partir do exterior". Isso significava que as antigas potências imperialistas já não tinham interesse em controlar de dentro as antigas colônias, mas sim em ajudá-las a desenvolver-se e em substituir uma presença visível por um governo imprevisível, o dos grandes bancos: Fundo Monetário Internacional, Banco Mundial etc. Os povos colonizados puderam assim livrar-se dos colonos, mas não do imperialismo nem de certos traços do colonialismo. Pode-se, portanto, falar de um imperialismo das multinacionais; porém, dada a interferência desses interesses com os dos Estados, pode-se 
igualmente falar de um imperialismo multinacional. Ora, pouco a pouco este foi dominado pelos americanos: hoje, entre as 200 principais multinacionais, 74 são controladas pelos Estados Unidos, 41 pelo Japão, 23 pela Alemanha, 19 pela França, 13 pelo Reino Unido, 6 pela Suíça: ou seja, $88 \%$ do total pertencem a esses países (Ferro 2004: 35-36).

A interferência dos organismos internacionais na economia e política dos países periféricos é oriunda da assimetria de poder exercidos pelo capital financeiro. O Estado, ente enfraquecido pelas interferências do poder econômico e midiático, tem diuturnamente implodido as bases sociais e democráticas numa América Latina endividada. As repúblicas engendradas na turbulência, ou será que sempre foram enviesadas pelas práticas econômicas, pautadas por decisões que têm fulcro em manter o Produto Interno Bruto acelerado atrelado à dependência dos recursos naturais para agradar os investidores nacionais e internacionais, como mostra a Figura 1.

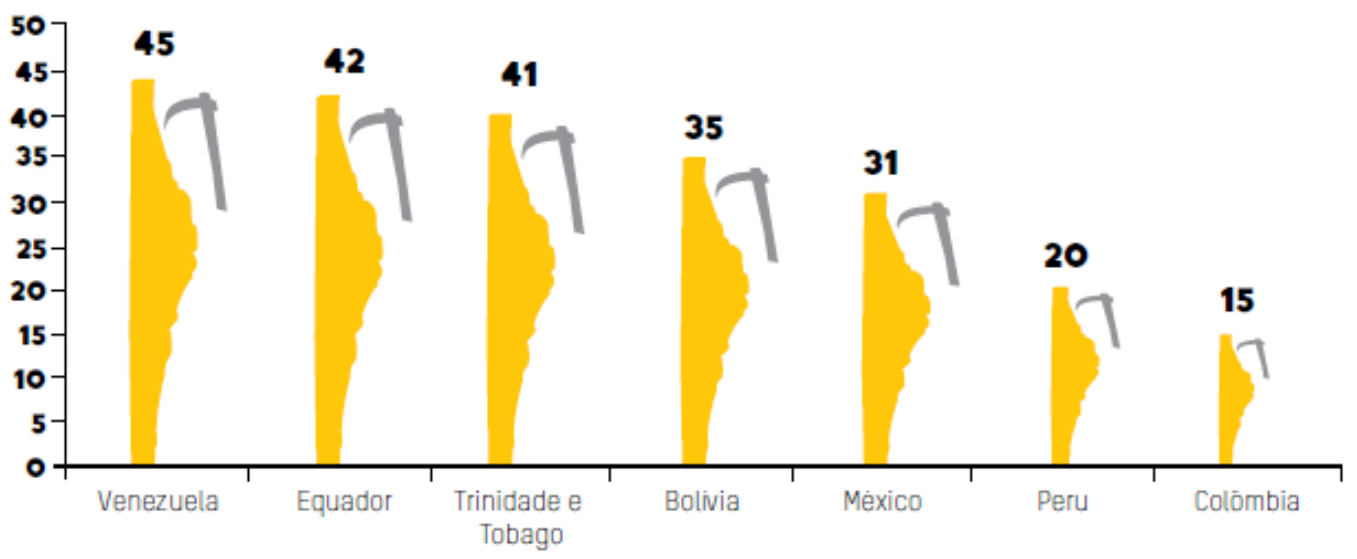

Figura 1. Depedência fiscal de recursos naturais para vários países da ALC (\% das receitas públicas), 20102013. Fonte: OXFAM (2015) com base na Comissão Econômica para a América Latina e o Caribe (CEPAL).

A utilização secular dos recursos naturais faz com que os países periféricos sejam mais dependentes destes e impedem o debate da sua escassez, limitação e baixo valor agregado, além dos problemas socioambientais que vêm consignados no modelo primário agroexportador reforçando a retroalimentação do subdesenvolvimento.

Historicamente, as tensões que desencadeiam os usos, direitos e concessão para exploração, pagamento por commodities e política externa têm sido constantes entre as nações com interesses distintos entre o pagamento da dívida interna e externa, amortização de juros, e atender aos estritos interesses das classes sociais e políticas estabelecidas. As esferas políticas ${ }^{3}$, atualmente existentes, referendam o status quo de demasiada exploração, privilégios e poder concentrado por uma ínfima parcela nacional e internacional de ${ }^{3} \mathrm{La}$ usurpación del Estado por los intereses privados condujo a intervenciones estatales que entorpecieron el funcionamiento eficiente del mercado y promovieron el rentalismo, la especulación y la corrupción. A su vez, las políticas públicas capturadas por intereses particulares no pudieron responder a las demandas de la mayoría de los ciudadanos, contribuyendo así a excluir de los beneficios del crecimiento a amplios sectores de la población y a la pérdida de legitimidad del Estado (Iglesias 2006: 10). pessoas que ocupam uma superestrutura social.

O processo de globalização serviu para romper barreiras, derrubar fronteiras e abrir os mercados para consumo de mercadorias e serviços, mas, também, para facilitação das trocas injustas de insumos e recursos entre os países. Na conjuntura da globalização, a influência dos mercados ou o seu controle sobre os Estados nacionais têm trazido uma usurpação de valores humanísticos e éticos em prol da perpetuação e aumento do capital para poucos indivíduos, conforme mostra a Figura 2. A globalização permite o fluxo de capitais e de mercadoria, não de pessoas. A restrição para as pessoas são cada vez mais significativas. Obviamente, consoante a isso, há uma acumulação da riqueza global concentrada a poucos sujeitos. 


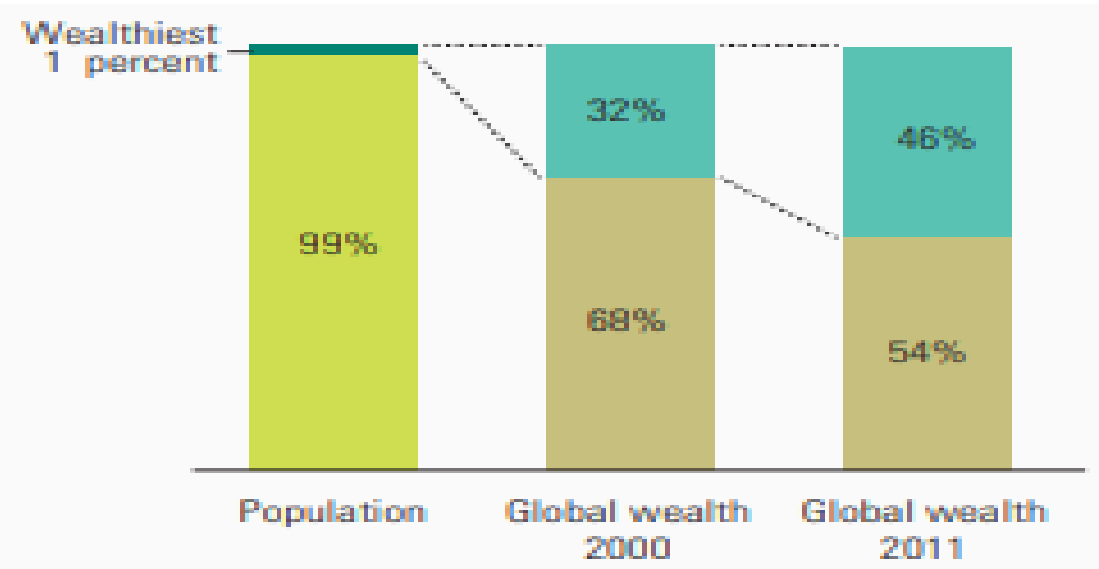

Figura 2. Concentração da riqueza global entre os anos de 2000 e 2011 com base nas estimativas do Relatório de Desenvolvimento Humano. Fonte: Milanovic (2016).

A Figura 2 comprova o aumento de $32 \%$ para $46 \%$ da concentração de riqueza por parte do $1 \%$ mais rico da população mundial. Um crescimento da concentração de riqueza da ordem de $14 \%$ nas mãos de apenas $1 \%$ da população mundial. Enquanto isso, a riqueza produzida mundialmente a ser compartilhada entre os $99 \%$ da população caiu. Os $99 \%$ da população teve sua riqueza reduzida de $68 \%$ para $54 \%$, o que agrava o nível de vida das pessoas pobres e indigentes globalmente.

A interdependência entre as origens da riqueza e seus donatários atuais mostra a necessidade de se repensar a extração de commodities sob o fajuto argumento de desenvolvimento, crescimento, geração de renda e emprego. As demandas orbitam em volta do mais poderoso, rico e influente império do sistema financeiro e político mundial, reduzindo a importância e necessidade do Estado enquanto redutor das desigualdades e excessos dos detentores do capital. A situação se tornou insustentável nas democracias ocidentais, causando um prejuízo maior para os países emergentes. A Tabela 1 mostra os 10 bilionários mais ricos da América Latina e do Caribe mostrando o setor ou ramo de atividade econômica em que atuam.

Tabela 1. Listagem ordenada das dez pessoas mais ricas da América Latina e do Caribe e ramo de atividade econômica em que atuam. Fonte: Forbes apud OXFAM (2015).

\begin{tabular}{ccccccc}
\hline $\begin{array}{c}\text { Posição } \\
\text { ALG }\end{array}$ & $\begin{array}{c}\text { Posição } \\
\text { mundial }\end{array}$ & Nome & Fortuna & País & Setor & Setor \\
\hline 1 & 2 & Carlos Slim Helu & $\$ 77.100,000$ & México & telecom & Telecoms \\
2 & 26 & Jorge Paulo Lemann & $\$ 25.000,000$ & Brasil & cerveja & Bebidas \\
3 & 52 & Joseph Safra & $\$ 17.300,000$ & Brasil & bancos & Finanças \\
4 & 77 & German Larrea Mota Velasco & $\$ 13.900,000$ & México & mineração & Extrativismo \\
5 & 82 & Iris Fontbona & $\$ 13.500,000$ & Chile & mineração & Extrativismo \\
6 & 85 & Luis Carlos Sarmiento & $\$ 13.400,000$ & Colômbia & bancos & Finanças \\
7 & 89 & Marcel Herrman Telles & $\$ 13.000,000$ & Brasil & cerveja & Bebidas \\
8 & 110 & Carlos Alberto Sicupira & $\$ 11.300,000$ & Brasil & cerveja & Bebidas \\
9 & 121 & Alberto Bailleres González & $\$ 10.400,000$ & México & mineração & Extrativismo \\
10 & 165 & João Roberto Marinho & $\$ 8.200,000$ & Brasil & mídia & Mídia \\
\hline
\end{tabular}

A origem dessas fortunas concentradas nas mãos de 10 pessoas não é casual. É fruto de decisões políticas e concessões econômicas que oneram a sociedade e beneficiam os setores econômicos em que atuam como: mídia, bancos, financeiro, mineração, extrativismo, telecomunicações etc. Isso provoca uma ilusão de que há uma interface entre necessária a extração destes recursos e o desenvolvimento econômico. $\mathrm{O}$ simulacro serve como pano de fundo para perpetuação do modelo colonial sendo nada mais que desenvolvimentismo. A constituição dessas elites em países latinoamericanos sob forte indução, incentivo e dedução fiscal por parte dos seus respectivos Estados, corrobora com a manutenção de estruturas de poder injustas e desiguais: 
Elites políticas e econômicas influem na gestão das políticas dos Estados, instalando políticas que não beneficiam a maioria, mas que são eficazes para maximizar os lucros e ganhos de uns poucos privilegiados, negando os direitos de muitos. $\mathrm{E}$ os meios nos soam tristemente conhecidos: tráfico de influências, lobby ilícito, corrupção em contratos públicos, clientelismo, compra de votos, concentração de meios de comunicação. Quanto mais a desigualdade aumenta, menos as pessoas confiam no sistema democrático. Não é só a qualidade da democracia que está em jogo, mas sua própria permanência. Por isso, os Estados devem adotar medidas urgentes para enfrentar a desigualdade. Os cidadãos latino americanos e caribenhos estão fartos da desigualdade. Observam-se níveis cada vez maiores de protesto diante de tanta injustiça (Oxfam 2015: 7).

Assim, o Estado opta por beneficiar as elites e seus negócios, mantendo uma estrutura de privilégios para estes em detrimento das demais camadas e segmentos da população. Há uma canalização e tomada de decisões que atuam na linha de frente para acentuar as disparidades de renda, acesso a crédito, investimento em setores estratégicos que beneficiem tais grupos econômicos. Nessa toada, a própria existência das condições da vida humana para todos com dignidade $^{4}$ tem sido obstadas pela prepotência das transnacionais, sistema bancário e financeiro dos organismos transnacionais e seus executivos em conluio com legisladores e governantes locais. A desintegração do Estado Social, em virtude do conluio entre políticos e empresários que usurpam dos poderes políticos e estatais para fazer escambo do patrimônio ambiental público e coletivo, remonta à épocas coloniais:
${ }^{4} \mathbf{E}$ justamente neste sentido que assume particular relevância a constatação de que a dignidade da pessoa humana é simultaneamente limite e tarefa dos poderes estatais e, no nosso sentir, da comunidade em geral, de todos e de cada um, condição dúplice esta que também aponta para uma paralela e conexa dimensão defensiva e prestacional da dignidade. Como limite, a dignidade implica não apenas que a pessoa não pode ser reduzida à condição de mero objeto da ação própria e de terceiros, mas também o fato de a dignidade gerar direitos fundamentais (negativos) contra atos que a violem ou a exponham a graves ameaças. Como tarefa, da previsão constitucional (explícita ou implícita) da dignidade da pessoa humana, dela decorrem deveres concretos de tutela por parte dos órgãos estatais, no sentido de proteger a dignidade de todos, assegurando-lhe também por meio de medidas positivas (prestações), o devido respeito e promoção (Sarlet 2008: 33).

\begin{abstract}
As consequências de uma cultura política marcada pelas heranças colonialistas, patrimonialistas e clientelistas, combinadas com as imposições de uma ditadura militar e econômica, geraram, na sociedade brasileira, um resultado visivelmente contraditório. De um lado, setores organizados das classes populares e aliados foram responsáveis por uma sociedade civil viva e razoavelmente mobilizada, para alcançar uma democracia política e econômica. De outro lado, diante das graves crises econômicas verificadas nos anos $1980 \mathrm{em}$ diante, os movimentos de perspectiva emancipadora, em alguns aspectos perderam o foco, por exemplo, perante a onda de crescente desemprego. E a massa da população desorganizada ficou, ou excluída da ação estatal, ou cada vez mais refém de ações públicas compensatórias combinadas com as políticas neoliberais que sustentam a reestruturação produtiva e a hegemonia do capital (Pedrini et al. 2007: 227).
\end{abstract}

As consequências históricas de um passado colonial, escravocrata e patrimonialista deixaram as marcas do "primeiro eu" e os meus, da apropriação do patrimônio público como se fosse privado, do uso da máquina pública sem critério e objetividade construindo uma teia de relações que se imiscuem do bem comum, do interesse social e coletivo para benefício privado. Desenvolvimento às custas do povo latinoamericano ou quaisquer outro, perfazendo uma conta desproporcional entre os reais beneficiários desse "progresso" ou agenda econômica que requer um questionamento dos reais ganhos sociais e democráticos do modelo hegemônico colocado. Em caso de se considerar o índice de Gini como referência para medir a desigualdade de renda sendo, quanto mais próximo de 1 muito desigual, e quanto mais próximo de 0 , menos desigual, tem-se o seguinte conforme a Figura 3: 


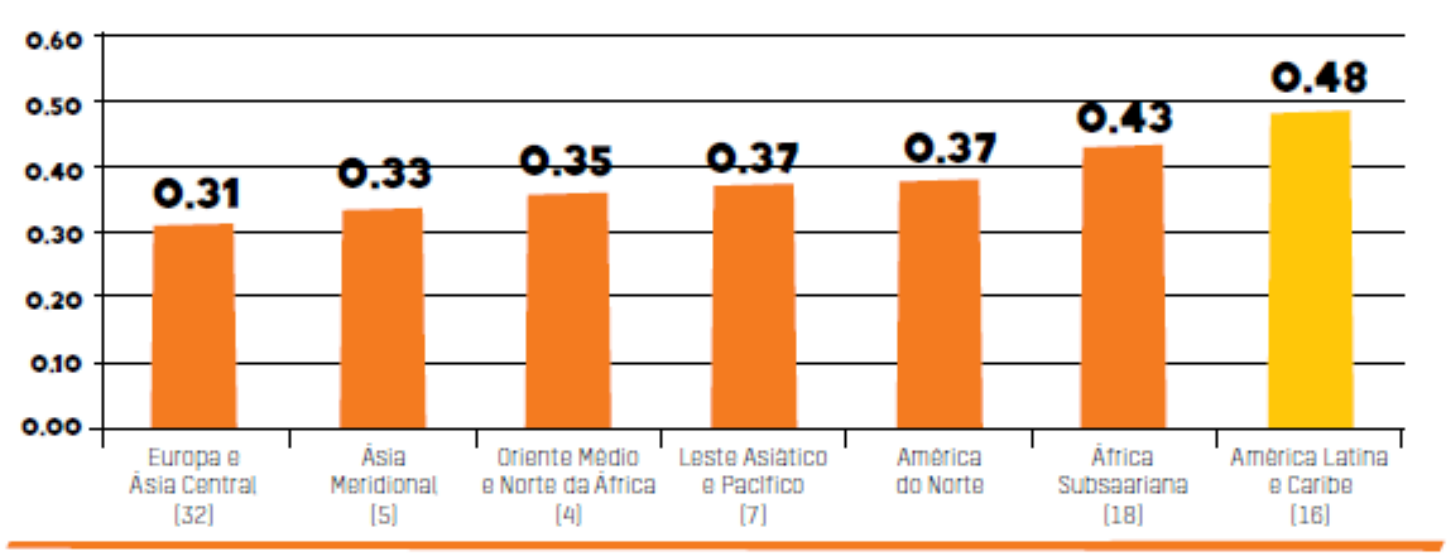

Figura 3. Índice de Gini de concentração de renda por região (2012) com base na Organização das Nações Unidas para Alimentação e Agricultura (FAO): Censo Agropecuário Mundial (CAM) do ano de 1990. Fonte: FAO apud OXFAM (2015).

O número elevado 0.48 para o índice de Gini dos países latinoamericanos e caribenhos mostra o sério problema da concentração de renda na região. Dessa maneira, a desigualdade e a concentração contribuem para disputas socioespaciais, de poder, de participação e não consolidação dos direitos sociais formalmente, mas não materialmente, inscritos na constituição federal. Os problemas sociais são retroalimentados através da espoliação dos recursos naturais, ironicamente, usados na ordem político-econômica como gerador de renda e emprego. Mero recurso estilístico dos políticos e empresários para justificar os meios utilizados no processo produtivo, ignorando ou diminuindo suas consequências.

\begin{tabular}{|c|c|}
\hline 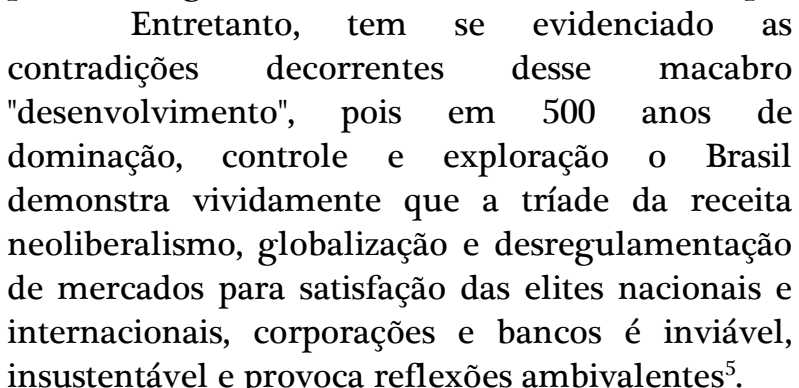 & $\begin{array}{l}{ }^{5} \mathrm{O} \text { desenvolvimento é reduzido a um simples } \\
\text { subproduto do que se entende por "plena } \\
\text { vigência dos mecanismos de mercado", ainda } \\
\text { que a custo do prejuízo eventual das dimensões } \\
\text { tidas por subsidiárias como meio ambiente, } \\
\text { educação, saúde etc. Na verdade, a fragmentação } \\
\text { e a pulverização das instâncias de decisão da } \\
\text { política ambiental exprimem o fato de que a } \\
\text { questão ambiental não é ainda uma questão de } \\
\text { Estado no Brasil (Acselrad 2001: 87). }\end{array}$ \\
\hline
\end{tabular}

Em verdade, o que fica claro é a manipulação e supremacia nesse campo de disputa por parte de uma minoria infinitamente rica, dotada de poder político, econômico, financeiro e midiático, estabelecida nesses estados, utilizando-se e sacando os bens ambientais de todos, enquanto que a maciça população e o próprio Estado tem sofrido um revés em termos de estoques de seu patrimônio, qualidade de vida, legitimidade e efetividade de direitos. Afinal, tais direitos são materialmente usufruídos na prática por uma seleta predileção de seres humanos uma casta superior de políticos e empresários, magnatas e tecnocratas - excluindo os demais seres que são tidos como párias, está se sofisticando para um patamar pragmático em termos de economicismo, pondo em risco a coesão social:

\footnotetext{
A realidade do sistema e suas promessas são incompatíveis. Logo, quando os ideais prometidos no capitalismo se anulam, pois inviabilizam o sistema, caso liberdade e igualdade sejam oportunizados a todos. Esses conceitos e valores são reais e objetivos, organicamente gerados pelo próprio sistema de mercado e dialeticamente ligados a ele de maneira indissociável. O sistema é mantido e perpetuado graças à desigualdade, acúmulo, retroalimentando as mazelas sociais de uma esmagadora maioria para incrementar o rendimento e privilégios de poucos (Jameson 1996: 280).
}

As classes superiores, em termos de dominação da produção e detentora das condicionantes econômicas, pois o triunfo é quase sempre monetário e só, são alinhadas com o dominador, aspirando o executar bem o papel de agressor, capataz e se espelhando nos modos, 
usos e costumes dos europeus e estadunidenses. Modelo está fracassado, mostra evidências de ruínas, que pode haver questionamentos sobre permanecer preso a ele.

Esse prognóstico sucinto implica em consequências de ordem econômico-ecológica, das relações contraditórias entre sociedade e seu meio ambiente, dão nitidez para outras maneiras de construir relações, rever identidades e leituras acerca de do mundo viável com uma meta-cidadania ${ }^{6}$, pondo em xeque a monocultura, exportação e latifúndio. Com o fim dessa tríade exploratória herdada de tempos coloniais, as bases da antiga e atual fonte primária que lança ao mundo os produtos primários dos países pobres, causando mais problemas de ordem social, ambiental e econômica, que benefícios. As instituições e política externa dos países centrais ou do norte geográfico se mostram aliadas de primeira grandeza com os abastados nacionais das nações subdesenvolvidas. Há uma relevância aos países centrais do Norte em detrimento aos países pobres do hemisfério Sul:

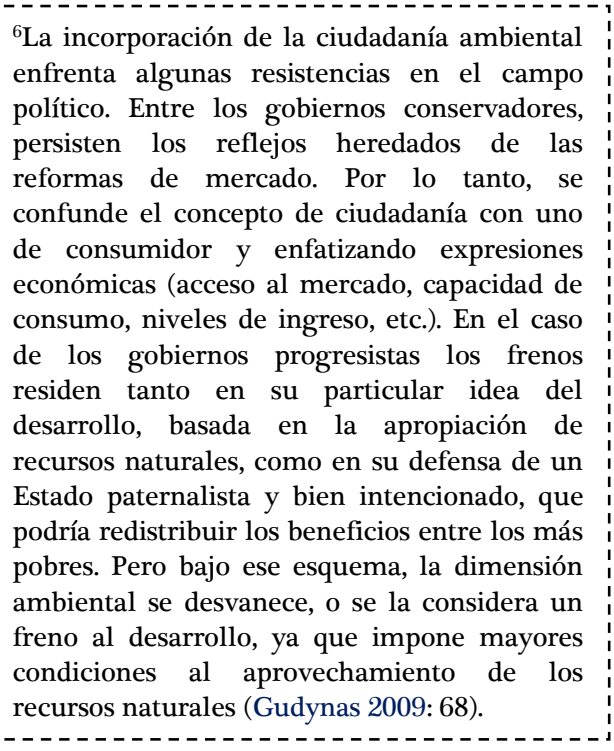

${ }^{6} \mathrm{La}$ incorporación de la ciudadanía ambiental persisten los reflejos heredados de las reformas de mercado. Por lo tanto, se confunde el concepto de ciudadanía con uno de consumidor y enfatizando expresiones economicas (acceso al mercado, capacidad de de los gobiernos progresistas los frenos residen tanto en su particular idea del desarrollo, basada en la apropiación de recursos naturales, como en su defensa de un Estado paternalista y bien intencionado, que pobres. Pero bajo ese esquema, la dimensión ambiental se desvanece, o se la considera un freno al desarrollo, ya que impone mayore recursos naturales (Gudynas 2009: 68).

\begin{abstract}
Uma vez conseguido um acordo no Norte, o Sul protesta e uma nova negociação inicia. Adentra-se o reino das relações internacionais. $O$ poder (militar, tecnológico e financeiro) do Norte, apesar de enormemente superior ao do Sul, não é facilmente mobilizável para o conflito específico. Países como a China e a Índia dispõem de uma arma poderosa: o seu poder de obstruir. Se eles se recusam a assinar, devem ser induzidos a isso, por exemplo, através de algumas propostas financeiras, como a transferência de tecnologia sob condições concessivas (Lipietz 1997: 151).
\end{abstract}

Logo, a constante situação dos países emergentes é de barganha e está à deriva no contexto internacional por causa das relações internacionais desiguais, à exceção de China e Índia que exigem contrapartida que pode vir sob a forma de transferência de tecnologia. Devido a isto, a vulnerabilidade em graus variados de dependência ou subserviência aos interesses internacionais na seara militar, tecnológica e financeira se refletem em expoliação da biodiversidade e das pessoas do Sul global ${ }^{7}$. Devido às constantes mutações do sistema capitalista para sobreviver e se retroalimentar dos sistemas sociais e ambientais vivos, é sempre árdua a tarefa de encontrar soluções. Afinal, quando se constrói uma alternativa ao sistema imposto, ela já não está condizente com a nova sistemática e suas dinâmicas em plena metástase:
Pero la gravedad y complejidad de la crisis financiera ha ido evolucionando con el tiempo hasta llegar a convertirla en sistémica, al afectar a la economía en su conjunto, al mercado laboral, a las instituciones, a las políticas e incluso a los valores morales y éticos. Hay que tener en cuenta, además, que esta crisis sistémica es, a su vez, una crisis mutante, al estar sometida a continuos y acelerados cambios, y una crisis global, al estar incidiendo en todo el planeta. No es, sin embargo, una crisis uniforme, puesto que afecta a los territorios con distintas formas e intensidades, ya se trate de países, regiones, ciudades o ámbitos rurales (Barroso 2014: 608). 
A crise financeira se alastrou e adentrou os meandros das instituições, do mercado laboral, da economia, das políticas e inclusive dos valores morais e éticos. É como um hospedeiro, um vírus que se espalha sem ser notado, mas que age intensamente no organismo que o recebe. Assim, o Estado nacional, não apenas o Brasil, de forma majoritária está sendo eclipsado pelas ingerências do capital através de executivos, empresários e agentes políticos que operam à serviço de interesses escusos e privados. Claramente, os impactos das mutações do capital são sentidos de maneiras e gradações diversas nos países, conforme sua permeabilidade nos centros e periferias. Essa infiltração na máquina pública marca uma era de expressivos recessos na cidadania, direitos humanos $^{8}$, pulverização e enfraquecimento da questão socioambiental, erodindo as questões de Estado para os transformar em recurso, mercadoria, serviço que possam ser posteriormente privatizados.

O desenvolvimento tido como maximização do lucro para poucos em detrimento do passivo socioambiental provocado, para acúmulo consecutivo da riqueza por parte de um grupo. A economia de livre mercado calcada no neoliberalismo e sob a batuta da globalização vêm alinhado à assimetria de poder, dicotomias e uma deterioração das relações entre países. Não obstante, a crise ecológica é resultado de uma ideologia unilateral e indiscutível que remete ao cerne do polo civilizatório fulcrado no consumo, descarte, manipulação, exploração, acumulação e dependência por parte dos países latifundistas, agroexportadores, monocultores, de passado colonial com nítida participação de suas elites nacionais que gerem o próprio Estado para perpetuar seus privilégios:

A explicação está, talvez, nas características distintivas do próprio processo de formação dos nossos povos, que são sua intencionalidade, sua prosperidade e sua violência. Aqui, a metrópole colonialista teve um projeto explícito e metas muito claras, atuando da forma mais despótica. Conseguiu, quase de imediato, subjugar a sociedade preexistente, paralisar a cultura original e converter a população em uma força de trabalho submissa (Ribeiro 2010: 38).

A colonização foi um projeto meticuloso que desagregou os costumes, crenças e tradições locais ao dizimar os povos autóctones. Com o genocídio indígena, com a massiva inferiorização do nativo, tudo que era ameríndio passou a ser subestimado, sobrepondo a língua, a religião, a cultura e produtos da metrópole como ideal a ser perseguido. Nesse processo violento, após minar as bases das sociedades locais e implantar a escravidão tudo estava legitimado pelo estado colonial e pela própria igreja católica.

Assim o sendo, historicamente, as desigualdades implantadas para favorecer a horda dos exploradores que aqui se estabeleceram visam reproduzir as demandas inerentes aos detentores do poder político, econômico e social. A produção e reprodução das dinâmicas em função do mercado pressupõe uma periferia bem adestrada e sob controle das metrópoles globais com o desígnio do mercado de capitais. Dessa forma, a sociedade capitalista ${ }^{9}$ se capilarizou, ultrapassando barreiras linguísticas e culturais, tentando incutir com pretensa normalidade e naturalidade a desigualdade. As dinâmicas das periferias e a reprodução e produção de desigualdades tornam-se inquestionáveis e tendem a ser banalizadas. 


\title{
2. Dinâmicas das periferias e (re)produção das desigualdades
}

$\mathrm{Na}$ esteira das contradições e dilemas referentes ao próprio sistema hegemônico, o controle das classes capitalistas nacional e internacional estão pautadas por um Estado que secularmente tem assegurado seus interesses. A manutenção desses privilégios para uma casta significa negar a participação e inclusão das classes desfavorecidas no compartilhamento da riqueza já produzida e dos excedentes acumulados por poucos ao longo de séculos de exploração e benefícios. Nesse sentido, a engrenagem da competição demasiada está liberada e até validada pelo modelo econômico.

Ademais, conforme o excerto abaixo, é possível traçar um paralelo entre o sistema produtivo, a relação do capital com a sociedade e as implicações decorrentes dessa sinergia para o meio ambiente físico, natural e transformado. Mais do que isso, é urgente definir o que seria cidade, seus usos e costumes, a possibilidade de negócios e trocas, o intercâmbio entre os seus habitantes nesse imenso parque humano consolidado hoje como lugar de reprodução não só das mazelas sociais, mas também do florescimento de ideias, expectativas, planos e performances por quem a habita e refaz diuturnamente:
${ }^{9} \mathrm{~A}$ sociedade capitalista afluente possui um lado ordeiro ao Norte, e um lado desordeiro ou caótico ao Sul. Não parece ser possível espalhar pelo mundo inteiro um modo de vida e de trabalho, que, em primeiro lugar, se baseia em um elevado consumo energético e material; que, em segundo, precisa dispor de sistemas energéticos e de transformação material eficientes e inteligentes; e que, em terceiro, precisa realizar e organizar nesta base uma prática de vida europeia-ocidental, com os correspondentes modelos ideológicos e de pensamento e instituições políticas e sociais reguladoras (Altvater 1995: 25).

\begin{abstract}
A cidade pode ser definida como sendo a forma, a materialidade, ou seja, os prédios e construções, as ruas, o asfalto, os postes, os viadutos etc. Já o urbano pode ser definido como sendo o conteúdo, as relações que se passam em tal materialidade. Como, então, mensurar relações? Há de se lançar mão de uma medida indireta: a população. É de se esperar que as relações que se passam numa cidade com vinte mil habitantes não sejam as mesmas que as que se passam numa com vinte milhões. Porém, convém ressaltar que tal artifício contém imperfeições, por exemplo, uma cidade com uma população de um milhão em Taiwan não significa a mesma coisa que outra com um milhão no Brasil, e esta cifra também possui significações diferentes ao longo do tempo. Apesar disso a taxa de urbanização (de um país, estado etc.) é dada pela porcentagem da população urbana em relação à população total (São Martino 1995: 99).
\end{abstract}

A cidade, assim como um país, é composta pela dimensão humana, cultural, econômica, histórica e a base material que possibilitou sua expansão e continuidade. A urbanização brasileira e, grosso modo, a latinoamericana, foi realizada acomodando os interesses coloniais e das burguesias apadrinhadas, clientelistas e patrimonialistas. Feito essa digressão, convém alinhar as práticas desenvolvidas mundialmente pelo capital para sua expansão, mesmo diante da inviabilidade deste projeto autodestrutivo e que piora as condições de vida na urbe:

o que se observou ao longo do desenvolvimento capitalista foi que a tecnologia aumentou o poder de intervenção na natureza, até mesmo de reinvenção da natureza, mas não conseguiu resolver a questão da utilização irracional dos recursos. Qual é o risco que se corre ao generalizar na China, por exemplo, o padrão de consumo americano? Isso acaba com o mundo, e acaba logo, pois não é só a questão da agressão aos recursos naturais, mas também de agressão às condições de convivência humana. $\mathrm{O}$ modelo de transporte individual que está aí é inviável, sua generalização é inviável, não só pelos efeitos ambientais, mas porque as cidades estão ficando francamente inabitáveis. Isso tudo tem a ver com o capitalismo do final do século XIX e do XX, que foi a generalização dos bens duráveis, dos automóveis etc. (Ismael et al. 2011a: 430-431).

O paradigma da atualidade é se os países em vias de desenvolvimento pretendem seguir a cartilha neoliberal e o consumismo de bens de produção em larga escala, subtraindo suas riquezas naturais e baixando a qualidade de vida de suas populações para benefício do individualismo momentâneo. Nessa esteira, torna-se mais cristalino fazer um comparativo da 
periferia do sistema mundo no qual os países subdesenvolvidos estão inseridos e a periferia de suas cidades. Não apenas a periferia enquanto subúrbio de metrópoles e grandes cidades, mas o conjunto de aglomerados urbanos excluídos dos serviços públicos, do reconhecimento e atuação estatal. Esta dinâmica que pode ser objeto de análise para aferir a desigualdade crescente nas cidades:

\begin{abstract}
O contraste entre o rico e o pobre em quase toda "cidade global" se reproduz na aldeia global, entre o Norte e o Sul. Nas cidades, os ricos se enclausuram em fortalezas, recolhem-se em condomínios cercados de muralhas e rigorosa vigilância, protegendo-se contra as ondas da pobreza, cujos modos de acesso às migalhas da riqueza, como se isso já não bastasse, são ainda por cima criminalizados. $\mathrm{Na}$ aldeia global erguem-se fortalezas, constroem-se cercas e muros contra os migrantes, que reivindicam para o mercado de trabalho apenas aquilo que constitui norma óbvia para a troca de mercadorias: liberdade de comércio e conduta. O mundo unificado é um mundo dividido (Altvater 1995: 25).
\end{abstract}

Os muros existem para as pessoas, os entraves são para os seres humanos, principalmente aqueles oriundos da periferia que buscam melhores condições de vida e trabalho do outro lado das fronteiras. Porém, o capital tem livre circulação, com a máxima da tecnologia e globalização, enquanto que as pessoas enfrentam barreiras, vistos, passaportes, condicionamentos para entrar, circular, permanecer, sair. Nesse mundo dividido por instabilidade político-econômica permanente, a crise migratória já se tornou um componente a mais para motivar a imigração daqueles que saem dos países-celeiro, dos países-mineiros, tentando fazer a mesma rota que só é permitida e bem-vinda aos produtos e mercadorias oriundos da América Latina, África e outros renegados dos centros globais de decisão e controle:

Após uma década de crescimento econômico forte e inclusivo, a região da
América Latina e do Caribe encontra-se no quinto ano de desaceleração
econômica e no segundo ano consecutivo de contração do PIB. A deterioração
das condições externas, associada aos desafios domésticos, reduziu as
expectativas de crescimento regional para - $0.7 \%$ em 2015 com projeção de
queda da atividade econômica para - $1.3 \%$ em 2016 . Essas projeções mascaram
importantes diferenças intra-regionais. As economias sul-americanas, que têm
sido as mais duramente atingidas pela queda dos preços de produtos básicos e
pelo desaquecimento da China, deverão sofrer contração de $2.6 \%$ em 2016 . No
México, América Central e no Caribe, a menor dependência dos produtos
básicos e os vínculos mais estreitos com a economia dos Estados Unidos deverão
propiciar uma expansão modesta de $2.7 \%$ em 2016 . O crescimento lento,
possivelmente por um longo período, está ameaçando os ganhos sociais da
região obtidos com dificuldade. A parcela da população que vive com US\$ 2.50
por dia ou menos, o limiar da pobreza extrema na região, caiu de $24.5 \%$ em 2003
para $11.0 \%$ em 2013. Ao todo, 76 milhões de pessoas saíram da pobreza. Não
obstante esses ganhos, em 2014, $39 \%$ da população permanecia vulnerável a cair
na pobreza, e o aumento do tamanho da classe média desacelerou (Banco
Mundial 2016: 36 ).

Note-se que a medida para a região é precisamente o fator econômico. Evidenciando a análise puramente mecânica e economicista que o banco tem para um continente que comporta muito mais que números e porcentagens. Diante disso e da já demonstrada dependência fiscal dos países sobre seus recursos naturais, o que se mostra um equívoco do ponto de vista socioambiental, acentuando a marginalização, pobreza e miséria justo no entorno dos grandes projetos desenvolvimentistas. A dicotomia entre Produto Interno Bruto alto e Índice de Desenvolvimento baixo atrelado a alta desigualdade (Gini) coloca em xeque o crescimento econômico latino-americano. Assim, isso acaba por expor a vulnerabilidade estrutural dos que ganham até 2.50 dólar por dia. A racionalidade econômica e a pujança ocidental significam a exclusão de milhões de latinoamericanos. Assim, a Figura 4 permite visualizar a evolução da pobreza e da indigência na América Latina entre os anos de 1980 e 2015. 


\section{Retóricas do capital}
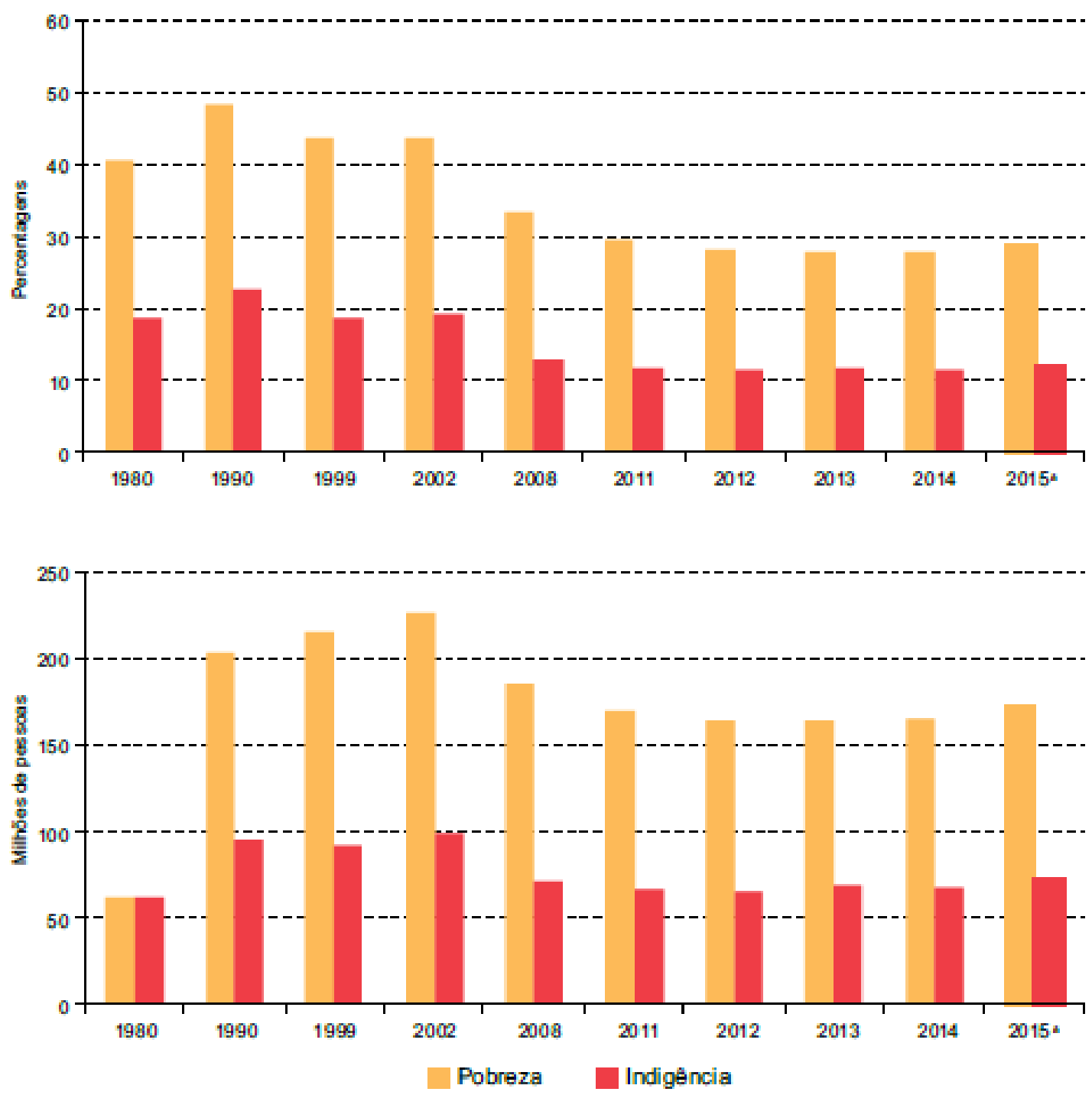

Figura 4. Evolução da pobreza e da indigência de 19 países da América Latina entre os anos de 1980 e 2015 em percentagem e milhões de pessoas com base em tabulações especiais das pequisas domiciliares. Fonte: CEPAL apud OXFAM (2015).

A pobreza e indigência se alternaram ao longo de séculos sendo a riqueza nacional subtraída pelas elites e os interesses estrangeiros, assim o índice de pobreza e a vulnerabilidade seguem o ritmo do crescimento econômico evidenciando a função concentradora e excludente do sistema capitalista ${ }^{10}$. Tal instabilidade acentua a permanente tensão entre as camadas sociais, as disputas por reforma urbana, direito à cidade, mobilidade urbana, educação, serviços de lazer, saúde e trabalho. Não obstante, existe uma interrelação com o passado colonial e o estabelecimento das cidades, assim como há uma conexão entre as escolhas políticas em alinhadas às decisões publica uma estimativa do total de bônus
concedidos aos altos executivos pelos bancos e
financeiras de Wall Street nos doze meses
anteriores. Em 2007, um ano desastroso para os
mercados financeiros, os bônus totalizaram 33.2
bilhões de dólares, apenas $2 \%$ menos que no ano
anterior. Em meados de 2007 , os bancos centrais
americano e europeu injetaram bilhões de
dólares em créditos de curto prazo no sistema
financeiro para garantir a sua estabilidade; em
seguida o Banco Central americano reduziu
drasticamente as taxas de juros e injetou vastas
quantidades de dinheiro no mercado a cada vez
que o índice da Bolsa de Valores ameaçava
despencar (Harvey 2016: 17 ). econômicas: 
vigilância, a arquitetura condominial-gentrificada das cidades e a formação de oligopólios que seguem a forma-Estado (corporações) atuando transnacionalmente com seu imenso poder de pressão plutocrático, tudo isso tem bem pouca relação com a teoria liberal, reduzida apenas a uma ideia regulativa que, na prática, funciona como "racionalização" no sentido freudiano (Pinto Neto 2016: 4-5).

O mercado praticamente obriga os estados a sucumbir diante das ameaças do sistema financeiro, tornando a democracia refém de políticas restritivas, de austeridade, que na verdade é o aniquilamento da cidadania. Depreende-se dessa lógica do condomínio que a gentrificação deve ser tutelada e abarcada por um Estado mínimo que defenda os interesses dos proprietários, que use da força militar contra seu próprio povo, que entre em convergência com os interesses para reprodução do capital e seus detentores:

Sem controles adequados, essa onda de "financeirização" se transformou na chamada crise das hipotecas podres e do valor dos imóveis. As consequências se concentraram, primeiro, nas cidades americanas e em torno delas, com implicações particularmente graves para os afroamericanos de baixa renda e famílias chefiadas por mulheres solteiras. A crise também afetou aqueles que, sem poder pagar os preços exorbitantes da habitação nos centros urbanos, foram forçados a morar nas semiperiferias metropolitanas. Nesses lugares, as pessoas compraram a juros, inicialmente baixos, casas padronizadas em condomínios construídos especulativamente; com a crise, passaram a enfrentar o aumento do custo do transporte para o trabalho e das prestações da hipoteca (Harvey 2016: $11)$.

É um processo bem delineado e orientado para fomentar a especulação imobiliária, a expulsão de pobres, a criminalização das minorias e dos indesejados, tido como sujeito-típico, construído pelo capital como agressor da propriedade privada. Ora, se a própria propriedade privada é ilegítima e fruto de séculos de compadrio e interesses escusos, a reivindicação dos direitos sociais a moradia, saúde, transporte público, educação e outros assegurados como direitos humanos básicos tem ampla prevalência, ao menos formalmente.

Ao passo que a engrenagem da exclusão e marginalização do pobre na cidade, deixando ele sequer de ser visto como detentor e sujeito de direitos, enseja uma nova política de invisibilização, negação e desqualificação das lutas e conquistas historicamente à civilização ocidental pós Revolução Francesa e Iluminismo. Justo num século altamente urbanizado, com densidade demográfica a cada dia mais elevada e com escassez de alguns elementos vitais aos seres vivos:

Consta das estatísticas demográficas mais recentes a confirmação de que a maior parte dos homens vive hoje nos espaços urbanos, o que teria produzido também a compreensão de ser o século XXI “o século da cidade", enquanto o XX teria sido o da urbanização. Nesta nova condição, a de civilização-humanidade urbana e, portanto, de alta densidade e concentração de pessoas no espaço, intensificam-se fluxos de toda ordem e a hibridização da natureza atinge suas potencialidades máximas. A cidade adquire, assim, o patamar ou nódulo central dos processos gerais derivados da sociedade humana sobre o espaço terrestre (Mendonça 2010: 154).

Assim sendo, a analogia das cidades como centros de fluxo e potencialização dos processos humanos cabe ser condizente com o sistema produtivo, gerando obviamente discórdias, tensões e conflitos ambíguos. Consoante a divisão internacional do trabalho ${ }^{11}$, nesse cenário, a riqueza dos países do Norte e a pujança econômica ali encontrada são possíveis graças às commodities que saem dos países do Sul Global e reforçam sua condição de subalternidade num sistema econômico extremamente desigual. A Tabela 2

${ }^{11}$ A antiga divisão internacional do trabalho
caracteriza-se pela utilização quase exclusiva dos
países do chamado Terceiro Mundo como ilhas de
sintropia dos países capitalistas centrais. Esta é uma
velha história. Pois, para os sistemas de
transformação energética manufatureiros e
posteriormente industriais, exploram-se cada vez
mais jazidas de matérias-primas e fontes de energia
em todas as regiões da Terra. Estas tendências,
iniciadas com o descobrimento da América Latina e
a subjugação colonial do continente africano e de
por toda a história do capitalismo moderno
(Altvater 1995: 180).


mostra a desigualdade econômica no mundo (1995) com base na renda conforme dados do Banco Mundial.

Tabela 2. Desigualdade econômica no mundo (1995) conforme dados do Banco Mundial. Fonte: Washington, Banco Mundial (World Development Indicators 1997 on CD-ROM) apud Estenssoro (2003).

\begin{tabular}{lcccc}
\hline & População (milhões) & \% População & PIB (US\$ milhões) & \% PIB \\
\cline { 2 - 5 } Países de renda alta & 903 & $15.91 \%$ & 22.508 .193 & $81.29 \%$ \\
Restante do mundo & 4.772 & $84.10 \%$ & 5.179 .129 & $18.71 \%$ \\
\hline
\end{tabular}

Note-se que a desigualdade econômica no mundo chega a ser da ordem de uma janela de, grosso modo, $20 \%$ da população mundial concentrando $80 \%$ da riqueza global produzida. Enquanto que, para $80 \%$ da população mundial resta dividir os $20 \%$ da riqueza global restante. Evidencia-se a discrepância na distribuição do PIB mundial ficando majoritariamente concentrado nos países de alta renda, que por sua vez tem somente $15 \%$ da população mundial. Ao passo que $84.10 \%$ da população mundial, o restante dos países periféricos, resta $18.71 \%$ do PIB global para atender suas necessidades. Sem a expoliação dos países do sul, não apenas dos recursos naturais, mas também das matérias-primas semiprocessadas ou recursos humanos abundante e barato, seria inviável manter a escala de produção e consumo na Europa, Estados Unidos, Japão, Austrália, além dos consumidores dos próprios países pobres.

A estabilidade da burguesia e das classes dominantes são assentadas sob uma escala social, delimitada por códigos reconhecidos pelo capital aonde quer que seja, graças a rapina justificada pelas elites como imposição da concentração de capital humano, cultural, econômico, político e simbólico diante da condição de escassez dos recursos naturais e energéticos. A desigualdade é vinculada ao privilégio das classes dominantes em ter uma dinâmica própria que a favoreça no território. $\mathrm{O}$ espaço é pré-definido para quem está no topo da pirâmide, pois as contradições inerentes do sistema evocam, no mesmo planeta, mundos paralelos e distintos conforme o poder de renda, relações produtivas e poder de interferência da classe social, aí sim, independente de seu lugar no mundo:

De outro lado houve uma mudança fundamental: a emergência de novos atores
na economia mundial, a China, a Îndia, a Ásia em geral, e o Brasil; as economias
BRIC, que representam hoje cerca de metade do crescimento mundial. Em
termos de contribuição ao crescimento global, hoje dois terços do crescimento
vêm das economias em desenvolvimento. Então a geografia econômica mundial
mudou. O velho esquema centro-periferia deixou de ter a validade, tal como foi
originalmente concebido (Ismael et al. 2011b: 409).

Nesse sentido, não é porque hoje há uma maior sinergia entre o mercado interno e altas taxas de urbanização nos países denominados BRICS que isso repercuta, obrigatoriamente, em qualidade de vida, distribuição de renda, demais índices de desenvolvimento e bem estar humanos. Ao revés, é por causa desse eufemismo do "desenvolvimento, economias em ascensão", que milhares de povos autóctones, comunidades tradicionais e pobres de periferias nos países não-desenvolvidos estão sendo expulsos e assassinados. Afinal, eles são o último "entrave", junto à algumas legislações específicas (Estatuto da Cidade, Constituição Federal de 1988) e tratados internacionais (ONU Habitat III, Pacto Internacional sobre Direitos Econômicos, Sociais e Culturais), que obstam a total mercantilização da cidade, do patrimônio histórico-cultural e relações urbanas, transformando tudo em mercadoria passível de compra, venda, consumo e distribuição.

Nessa vertente da realidade periférica, entendido periferia com sentido polissêmico, tanto periferia global quanto periferia da cidade, estar fora do circuito integrativo que permite a um ser humano se desenvolver, viver e se expressar. Para tal fim, a promoção da integração social é concebida como um direito conquistado e positivado que precisa ser diariamente reelaborado e reafirmado, embora não consolidado ainda por motivos de ordem políticoeconômica, constando de mecanismos e instrumentos que possibilitem ao ser humano sua inserção na sociedade de forma plena: 
Los profundos cambios y desafíos globales derivados de desequilibrios económicos, sociales y ambientales han evidenciado con más claridad que nunca la esencialidad de los derechos humanos para el desarrollo sostenible. El desarrollo no será sostenible ni inclusivo a menos que tenga a los derechos humanos como piedra angular. Los compromisos que los Estados han asumido en virtud del derecho internacional de los derechos humanos y aquellos vinculados a un nuevo estilo de desarrollo se refuerzan mutuamente y aspiran a un mismo objetivo: aumentar el bienestar humano y salvaguardar la dignidad de las personas. Se fundamentan en los conceptos de igualdad y universalidad. Establecen principios, estándares y valores comunes; apuntan a obtener bienes públicos globales; y afrontan preocupaciones colectivas, al tiempo que prestan especial atención a aquellos sectores más vulnerables de la sociedad (Pacto Internacional de Derechos Económicos, Sociales y Culturales 1966: 13).

O parâmetro deveria ser o bem estar humano e a dignidade das pessoas. Os compromissos dos Estados deveriam se pautar por padrões mínimos de princípios e valores que compartilhem a igualdade e universalidade dos bens públicos globais com os setores mais vulneráveis. Consubstanciado no exposto acima, tem-se que retornar à uma cidade como um lugar aprazível, que disponha de atributos e adjetivos positivos, construtivos que possa atingir à totalidade de seus cidadãos, transeuntes, turistas, moradores, viventes. Não apenas ser um lugar de troca, de intercâmbio para quem possui recursos e possa nela se mover, não mais um serviço ou mercadoria, uma cidade privatizada só retroalimenta os interesses mercadológicos, expulsando e negando a convivência entre os diferentes. Como pacificado está no Pacto Internacional de Direitos Econômicos, Sociais e Culturais, os Estados que o subscreveram estabelecem os direitos humanos, o bem estar humano, a dignidade, os padrões para um novo estilo de desenvolvimento que não crie excluídos, nem acentue a extrema pobreza ${ }^{12}$ :

${ }^{12}$ Extrema pobreza: los condicionantes
económicos adquieren una dimensión
superlativa cuando se suman a otros de
naturaleza social, cultural, laboral, etc., y
conducen a la marginación y exclusión social.
Los motivos de mayor gravitación por los que
los más pobres ven obstaculizado su acceso a la
justicia incluyen: a) la situación de indigencia;
b) el analfabetismo o la falta de instrucción e
información; c) la complejidad de los
procedimientos; d) la desconfianza, incluso el
miedo, debido a su negativa experiencia con la
justicia, sea porque a menudo se encuentran
en situación de acusados, sea porque sus
denuncias se vuelven contra ellos; e) la
lentitud de la justicia, a pesar de que sus
denuncias se refieren a menudo a aspectos
muy delicados de la vida que exigirían una
solución rápida, como la devolución de los
hijos, y f) el hecho de que en muchos países no
les está permitido hacerse acompañar o
representar por asociaciones de solidaridad,
que podrían también constituirse en parte civil
(Pacto Internacional de Derechos Económicos,
Sociales y Culturales 1966: 33 ).

Sociales y Culturales 1966: 33).

La Declaración y el Programa de Acción de Viena de 1993 afirman que todos los derechos humanos son universales, indivisibles e interdependientes y están relacionados entre síl. No en vano, ningún derecho puede disfrutarse de forma aislada, sino que ese goce depende de la realización de los demás derechos. Además, los tratados comparten principios fundamentales, como la igualdad y la no discriminación, la atención y la protección especial de los grupos más vulnerables, y el objetivo último de situar al ser humano como participante activo e informado de la vida pública y de las decisiones que lo afectan (Internacional de Derechos Económicos, Sociales y Culturales 1966: 17).

No entanto, na cidade, as relações urbanas tem se deteriorado, sendo um ambiente que na contemporaneidade tem gerado neuroses, obsessões, violência, zonas de alta concentração de riqueza e bem-estar em face de bolsões de miséria. A cidade como está posta, privatizada e pronta para servir aos que podem pagar pelos serviços (antes direitos, ao menos do ponto de vista formal), usufruem dela. No exemplo de São Paulo, a Rede Nossa São Paulo divulga o Mapa da Desigualdade:

São Paulo é a cidade mais rica do Brasil. Ao mesmo tempo, apresenta vergonhosos indicadores de desigualdade: dos 96 distritos da cidade, 31 não mantêm sequer um leito hospitalar; 34, nenhum parque; e em 36 não há uma biblioteca pública sequer. A diferença entre os indicadores do melhor e do pior distrito chega, em inúmeros casos, a milhares de vezes. A mortalidade infantil é 14.85 vezes mais grave no Pari do que em Pinheiros. Um novo dado é bastante 
emblemático e assustador: o tempo médio de vida do morador de Cidade Tiradentes é de 53.85 anos; no Alto de Pinheiros, chega a 79.67 (Grajew 2017: $10)$.

Como os dados acima mencionam, o índice de mortalidade infantil é distribuído desigualmente no território, assim como os serviços públicos, a riqueza, o acesso e fruição dos direitos sociais mínimos. A disparidade da mortalidade infantil de quase 15 vezes do Pari em relação ao bairro de Pinheiros possibilita afirmar que as condições de vida dos pobres não importam para os gestores públicos. No mesmo sentido, o tempo médio de vida de um morador do distrito Cidade Tiradentes é 26 vezes inferior ao de um morador do Alto de Pinheiros. Essa estatística precisa dos bairros paulistanos reflete desigualdades múltiplas que afetam os mais pobres por falta de bens e equipamentos essenciais para o desenvolvimento integral do ser humano:

\footnotetext{
Em grande parte dos 96 distritos de São Paulo não há instalaᄀções e serviços públicos adequados e suficientes. Enquanto um distrito mais central, como o Jardim Paulista, mantém uma taxa de $0.11 \%$ de adolescentes grávidas, em distritos na periferia, como Perus, adolescentes grávidas representam $19.41 \%$ do total de nascidos vivos. $\mathrm{O}$ índice de centros culturais, casas e espaços de cultura, por grupo de 10 mil habitantes, é de 3.58 no distrito da Sé (o melhor indicador da cidade), enquanto no Sacomã é de apenas 0.039 e, em São Mateus e outros 59 distritos, é zero. Em relação ao meio ambiente, os dados revelam que o total de área verde por habitante é 341.43 vezes maior em Parelheiros (o melhor índice) do que na Cidade Ademar (o pior), que possui apenas $0.77 \mathrm{~m}^{2}$ por habitante - a Organização Mundial da Saúde (OMS) recomenda um mínimo de $12 \mathrm{~m}^{2}$ de área verde por habitante (Grajew 2017: 11).
}

Esses números colossais elencam que, aos que estão à margem do sistema econômicoprodutivo, que não são desejáveis, como negros, índios, minorias, imigrantes, travestis e outros acontece um processo agressivo, por vezes sutil/simbólico e por hora brutal de desapropriação, de falta de políticas públicas bem traçadas e contínuas, de integração sociocultural, pois não é do interesse imobiliário, das classes altas e dos dirigentes privados e públicos que eles se estabeleçam e ocupem a cidade de maneira plena.

Logo, o processo de exclusão social e marginalização continuam, a concentração e especulação imobiliária são mecanismos utilizados com sucesso pela construção civil e até mesmo pelo poder público que expulsa o rejeito, o refugo, os indesejados que o próprio sistema criou com fins de fingir a resolução dos problemas implicados no próprio modelo adotado. Por fim, essa conjectura acaba por repelir os que não integram a sociedade na órbita economicista ou dentro das camadas historicamente aceitas e massificadas (brancos, patriarcal, machista, opressora, elitista, europeizada).

\section{Considerações finais}

Diante do panorama proposto pelo trabalho, tem-se como possíveis considerações finais uma pauta que, sinteticamente, põe em análise os paradoxos da ordem econômica vigente, seus compromissos assumidos e as consequentes implicações para a sociedade civil. Não obstante, a divisão internacional do trabalho, num espectro mais amplo visa direcionar as relações de produção, consumo e maneira como estão organizados o sistema produtivo em escala global para perpetuação das desigualdades inerentes ao sistema econômico vigente.

A desenvoltura do capital no século XXI é polida e promulgada como única via de conjugação dos interesses na lógica da financeirização da vida em torno do urbano. A cidade como fetichização, a subsequente gentrificação e disputa por espaços nobres de terra, o privilégio de habitar, viver e ser numa urbe é mediado pelo viés econômico. Ademais, a cidade se fragmenta nessa ótica neoliberal, pois as relações humanas se tornam individualistas, utilitaristas e segregadoras. Não obstante, a funcionalidade do racionalismo econômico impede a solidariedade e força a barbárie, negando os princípios democráticos e republicanos adotados nos países ocidentais. 
A ocorrência da comparação entre periferia e capital, entre colônias e países dominantes ou centrais, traz à baila questões que transcendem as barreiras geográficas. Tema de interesse das ciências sociais e humanas, as relações do sujeito consigo mesmo, seu agir e impressão na cidade e demais indivíduos ganham um contorno essencialmente subjetivo. A reprodutibilidade das desigualdades e assimetrias das relações humanas, estatais e privadas entre os países e dentro deles demonstra que existe uma complexa emergência em se conhecer e dialogar com os atores sociais interessados numa mudança significativa de horizonte pós derrocada do reducionismo econômico.

\section{Agradecimentos}

A Coordenação de Aperfeiçoamento de Pessoal de Nível Superior (CAPES) pela bolsa concedida ao primeiro autor. Aos avaliadores pelas valorosas contribuições ao manuscrito.

\section{Referências}

Acselrad H. (2001) Políticas ambientais e construção democrática (p. 75-96). In: Viana G., Silva M. \& Diniz N. (Orgs). O desafio da sustentabilidade: um debate socioambiental no Brasil. São Paulo: Fundação Perseu Abramo. 364 p.

Altvater E. (1995) O preço da riqueza. São Paulo: Universidade Estadual Paulista. 335 p.

Banco Mundial (2016) Washington, DC: Banco Mundial. Licença: Creative Commons Attribution - Non Commercial - No Derivatives 3.0 IGO (CG BY-NC-ND 3.0 IGO).

Barroso I.C. (2014) Los territorios en la crisis. Ciudad y Territorio Estudios Territoriales. Ciudad y Territorio Estudios Territoriales, 46(182): 607-624.

Bustos B., Prieto M. \& Barton J. (2015) Ecología Política en Chile: naturaleza, propiedad, conocimiento y poder. Santiago de Chile: Editorial Universitaria. 268 p.

Estenssoro L. (2003) Capitalismo, desigualdade e pobreza. Tese doutorado, Departamento Sociologia. Universidade de São Paulo. São Paulo.

Ferro M. (2004) O livro negro do colonialismo. Rio de Janeiro: Ediouro. 957 p.

Gonçalves C.W.P. (2002) Os (des)caminhos do meio ambiente. São Paulo: Editora Contexto. 152 p.

Grajew O. (2017) Mapa da Desigualdade revela as diferentes cidades dentro da capital paulista. Desigualdade em movimento. OXFAM, Brasil. Le Monde Diplomatique Brasil. Centro de Estudos da Metrópole.

Gudynas E. (2009) Ciudadania ambiental y meta-ciudadanias ecológicas: revision y alternativas en America Latina. Desenvolvimento e Meio Ambiente, 19: 53-72.

Harvey D. (2013) O Direito à Cidade. Folha de S. Paulo, São Paulo. Disponível em: https://piaui.folha.uol.com.br/materia/o-direito-a-cidade/ (Acessado em 06.03.2019).

Human Development Report (2016) Human Development for Everyone. New York: United Nations Development Programme. $272 \mathrm{p}$.

Iglesias E.V. (2006) El papel del Estado y los paradigmas económicos en América Latina. Revista de la CELPA, 90: 7-15.

Ismael R., D’Aguiar, R.F., Barbosa A.F. \& Ricupero B. (2011a) Luiz Gonzaga Belluzzo. Cadernos do Desenvolvimento, 6(9): 420-441.

Ismael R., D’Aguiar R.F., Salm C., Pinkusfeld C. \& Torres E. (2011b) Luciano Coutinho. Cadernos do Desenvolvimento, 6(9): 406-419.

Jameson F. (1996) O pós-modernismo e o Mercado (p. 279-296). In: Zizek S. (Org.) Um Mapa da Ideologia. Rio de Janeiro: Contraponto. 337 p.

Lipietz A. (1997) Cercando os bens comuns globais: negociações sobre o meio ambiente global em uma abordagem do conflito Norte/Sul (p. 147-186). In: Castro E. \& Pinton F. (Orgs). Faces do trópico úmido: conceitos e questões sobre Desenvolvimento e Meio Ambiente. Belém: Cejup, UFPA-NAEA. $445 \mathrm{p}$.

Mendonça F. (2010) Riscos e vulnerabilidades socioambientais urbanos: a contingência climática. Mercator, 9(número especial 1): 153-163. 


\section{Retóricas do capital}

OXFAM (2015) Privilégios que negam direitos: desigualdade extrema e captura política na América Latina e no Caribe. Relatórios de Pesquisa. 207 p.

Ozonas M.L. et al. (1995) População da sociedade de Neuquén. In: Santos M., Souza M.A.A., Scarlato F.C. \& Arroyo M. (Orgs). O novo mapa do mundo: Problemas geográficos de um novo mundo. São Paulo: HUCITEC. 406 p.

Pacto Internacional de Derechos Económicos, Sociales y Culturales (1966) Adoptado y abierto a la firma, ratificación y adhesión por la Asamblea General en su resolución 2200 A (XXI), de 16 de diciembre de 1966. Naciones Unidas, Derechos Humanos. Disponível em: http://www.ohchr.org/SP/ProfessionalInterest/Pages/CESCR.aspx (Acesso em: 29.06.2017).

Pedrini D.M., Adams T. \& Silva V.R. (2007) Controle social de políticas públicas: caminhos, descobertas e desafios. São Paulo: Paulus. 238 p.

Pinto Neto M.F. (2016) Esquecer o neoliberalismo: aceleracionismo como terceiro espírito do capitalismo. Cadernos IHU ideias, 14(245): 3-19.

Ribeiro D. (2009) A América Latina existe? Brasília: UnB. 111 p.

São Martino C.M. (1995) As cidades milionárias do Terceiro Mundo: a noção de macrocefalia (p. 99-105). In: Santos M., Souza M.A.A., Scarlato F.C. \& Arroyo M. (Orgs). O novo mapa do mundo: Problemas geográficos de um novo mundo. São Paulo: HUCITEC. 406 p.

Viégas R.N. (2009) Conflitos ambientais e lutas materiais e simbólicas. Desenvolvimento e Meio Ambiente, 19: 145-157. 